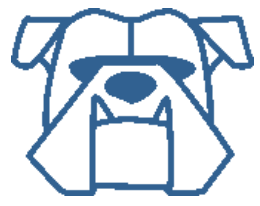

Kettering University

Digital Commons @ Kettering University

$9-1-2017$

Advanced Energy Storage Technologies and Their Applications (AESA2017)

Rui Xiong

Hailong Li

Xuan Joe Zhou

Follow this and additional works at: https://digitalcommons.kettering.edu/ electricalcomp_eng_facultypubs

Part of the Electrical and Computer Engineering Commons 


\title{
Advanced Energy Storage Technologies and Their Applications (AESA2017)
}

\author{
Rui Xiong ${ }^{1,2, *}$ (D), Hailong $\mathrm{Li}^{3,4}$ and Xuan Zhou ${ }^{5}$ \\ 1 National Engineering Laboratory for Electric Vehicles, Department of Vehicle Engineering, \\ School of Mechanical Engineering, Beijing Institute of Technology, Beijing 100081, China \\ 2 Faculty of Science, Engineering and Technology, Swinburne University of Technology, John Street, \\ Hawthorn, VIC 3122, Australia \\ 3 Energy Technology, School of Business, Society and Technology Mälardalens University, Box 883, \\ 72123 Västerås, Sweden; hailong.li@mdh.se \\ 4 Tianjin Key Laboratory of Refrigeration Technology, School of Mechanical Engineering, \\ Tianjin University of Commerce, Tianjin 300134, China \\ 5 Electrical and Computer Engineering Department, Kettering University, 1700 University Avenue, \\ Flint, MI 48504, USA; xzhou@kettering.edu \\ * Correspondence: rxiong@bit.edu.cn; Tel.: +86-10-6891-4070
}

Received: 24 August 2017; Accepted: 7 September 2017; Published: 9 September 2017

\begin{abstract}
This editorial summarizes the performance of the special issue entitled Advanced Energy Storage Technologies and Applications (AESA), which is published in MDPI's Energies journal in 2017. The special issue includes a total of 22 papers from four countries. Lithium-ion battery, electric vehicle, and energy storage were the topics attracting the most attentions. New methods have been proposed with very sound results.
\end{abstract}

Keywords: lithium-ion battery; electric vehicle; energy storage

To reduce the usage of fossil fuel and ease air pollution, many countries have put huge efforts to promote the development of electric vehicles. Lithium-ion batteries are the main power sources of electric vehicles, and have been the research focus in both industry and academia [1,2].

This special issue has focused on advanced energy storage technologies and their applications, which covers all kinds of energy storage and application fields, such as:

(1) Novel energy storage materials and topologies;

(2) Application in electrical/hybrid driven system and electrical/hybrid vehicles;

(3) Next generation energy storage devices, systems, or techniques;

(4) Large-scale energy storage system modeling, simulation and optimization, including testing and modeling ageing processes;

(5) Advanced energy storage management systems, including advanced control algorithms and fault diagnosis/online condition monitoring for energy storage systems;

(6) Business model for the application and deployment of energy storage;

(7) Lifecycle analysis, repurposing, and recycling.

After peer-reviewing, papers in high scientific quality and innovativeness were accepted. A total of twenty-two papers were accepted, with the following geographical distribution of authors:

(1) China (18).

(2) USA (2).

(3) Germany (1). 


\section{(4) Italy (1).}

The lithium-ion battery has been investigated broadly, including equivalent circuit modeling and parameter estimation [3,4], state of charge and peak power estimation [5,6], battery pack equalization [7], and battery capacity decay [8]. Recently, battery heating-related characteristics have been a research focus. Zhu et al. [9] investigated an impedance-based temperature estimation method considering the electrochemical non-equilibrium with short-term relaxation time for facilitating vehicular application. Hong et al. [10] developed a thermal runaway prognosis scheme for battery systems in electric vehicles based on the big data platform and entropy method. The low-temperature preheating techniques of lithium-ion batteries were investigated in [11,12].

The driving performance of electric vehicles (EVs) is highly dependent on the energy distribution of the power sources and the electronics' reliability. Energy optimization strategies and automatic control techniques were investigated in [13-15]. Ding et al. [16] investigated the impact of silicon carbide ( $\mathrm{SiC}$ ) metal oxide semiconductor field effect transistors (MOSFETs) on the dynamic performance of permanent magnet synchronous motor (PMSM) drive systems. In another paper, Ding et al. [17] investigated the impact of SiC on the powertrain systems in EVs.

Other energy storage forms have also been investigated aside from lithium-ion batteries or DC-DC, including superconducting magnetic energy storage (SMES) [18], latent thermal energy storage (LTS) [19], and compressed air energy storage [20]. Refs. [21,22] investigated the design of pump-turbines.

Two reviews are presented in this special issue. Lanahan et al. [23] analyzed recent case studies-numerical and field experiments—-seen by borehole thermal energy storage (BTES) in space heating and domestic hot water capacities, coupled with solar thermal energy. Benato et al. [24] offered a wide overview on the large-scale electrochemical energy projects installed in the high-voltage Italian grid. Detailed descriptions of energy (charge/discharge times of about $8 \mathrm{~h}$ ) and power intensive (charge/discharge times ranging from $0.5 \mathrm{~h}$ to $4 \mathrm{~h}$ ) installations were presented with some insights into the authorization procedures, safety features, and ancillary services.

Acknowledgments: Guest editors would like to express their sincerest gratitude to Energies' in-house editor and reviewers for their wonderful work and effort. Without their support, the efficient handling of all receive manuscripts, it would not have been possible to publish this special issue. Sincere gratitude is also expressed to the joint support by the National Natural Science Foundation of China under Grant No. 51507012 and Beijing Nova Program under Grant No. Z171100001117063.

Conflicts of Interest: The authors declare no conflict of interest.

\section{References}

1. Xiong, R.; Zhang, Y.; He, H.; Zhou, X.; Pecht, M. A double-scale, particle-filtering, energy state prediction algorithm for lithium-ion batteries. IEEE Trans. Ind. Electron. 2017. [CrossRef]

2. Xiong, R.; Yu, Q.Q.; Wang, L.Y.; Lin, C. A novel method to obtain the open circuit voltage for the state of charge of lithium ion batteries in electric vehicles by using $\mathrm{H}$ infinity filter. Appl. Energy 2017. [CrossRef]

3. Chen, D.; Jiang, J.; Li, X.; Wang, Z.; Zhang, W. Modeling of a Pouch Lithium Ion Battery Using a Distributed Parameter Equivalent Circuit for Internal Non-Uniformity Analysis. Energies 2016, 9, 865. [CrossRef]

4. Yang, J.; Xia, B.; Shang, Y.; Huang, W.; Mi, C. Improved Battery Parameter Estimation Method Considering Operating Scenarios for HEV/EV Applications. Energies 2017, 10, 5. [CrossRef]

5. Zhang, C.; Jiang, J.; Zhang, L.; Liu, S.; Wang, L.; Loh, P.C. A Generalized SOC-OCV Model for Lithium-Ion Batteries and the SOC Estimation for LNMCO Battery. Energies 2016, 9, 900. [CrossRef]

6. Jiang, B.; Dai, H.; Wei, X.; Zhu, L.; Sun, Z. Online Reliable Peak Charge/Discharge Power Estimation of Series-Connected Lithium-Ion Battery Packs. Energies 2017, 10, 390. [CrossRef]

7. Shang, Y.; Zhang, Q.; Cui, N.; Zhang, C. A Cell-to-Cell Equalizer Based on Three-Resonant-State Switched-Capacitor Converters for Series-Connected Battery Strings. Energies 2017, 10, 206. [CrossRef]

8. Wu, X.; Wang, T. Optimization of Battery Capacity Decay for Semi-Active Hybrid Energy Storage System Equipped on Electric City Bus. Energies 2017, 10, 792. [CrossRef] 
9. Zhu, J.; Sun, Z.; Wei, X.; Dai, H. Battery Internal Temperature Estimation for LiFePO4 Battery Based on Impedance Phase Shift under Operating Conditions. Energies 2017, 10, 60. [CrossRef]

10. Hong, J.; Wang, Z.; Liu, P. Big-Data-Based Thermal Runaway Prognosis of Battery Systems for Electric Vehicles. Energies 2017, 10, 919. [CrossRef]

11. Wu, X.; Chen, Z.; Wang, Z. Analysis of Low Temperature Preheating Effect Based on Battery Temperature-Rise Model. Energies 2017, 10, 1121. [CrossRef]

12. Zhang, C.; Jin, X.; Li, J. PTC Self-heating Experiments and Thermal Modeling of Lithium-ion Battery Pack in Electric Vehicles. Energies 2017, 10, 572. [CrossRef]

13. Liu, Y.; Li, J.; Ye, M.; Qin, D.; Zhang, Y.; Lei, Z. Optimal Energy Management Strategy for a Plug-in Hybrid Electric Vehicle Based on Road Grade Information. Energies 2017, 10, 412. [CrossRef]

14. Lei, Z.; Cheng, D.; Liu, Y.; Qin, D.; Zhang, Y.; Xie, Q. A Dynamic Control Strategy for Hybrid Electric Vehicles Based on Parameter Optimization for Multiple Driving Cycles and Driving Pattern Recognition. Energies 2017, 10, 54. [CrossRef]

15. Sun, J.; Xing, G.; Zhang, C. Data-Driven Predictive Torque Coordination Control during Mode Transition Process of Hybrid Electric Vehicles. Energies 2017, 10, 441. [CrossRef]

16. Ding, X.; Du, M.; Cheng, J.; Chen, F.; Ren, S.; Guo, H. Impact of Silicon Carbide Devices on the Dynamic Performance of Permanent Magnet Synchronous Motor Drive Systems for Electric Vehicles. Energies 2017, 10, 364. [CrossRef]

17. Ding, X.; Cheng, J.; Chen, F. Impact of Silicon Carbide Devices on the Powertrain Systems in Electric Vehicles. Energies 2017, 10, 533. [CrossRef]

18. Wang, X.; Yang, J.; Chen, L.; He, J. Application of Liquid Hydrogen with SMES for Efficient Use of Renewable Energy in the Energy Internet. Energies 2017, 10, 185. [CrossRef]

19. Kuboth, S.; König-Haagen, A.; Brüggemann, D. Numerical Analysis of Shell-and-Tube Type Latent Thermal Energy Storage Performance with Different Arrangements of Circular Fins. Energies 2017, 10, 274. [CrossRef]

20. Safaei, H.; Aziz, M.J. Thermodynamic Analysis of Three Compressed Air Energy Storage Systems: Conventional, Adiabatic, and Hydrogen-Fueled. Energies 2017, 10, 1020. [CrossRef]

21. Wang, Z.; Zhu, B.; Wang, X.; Qin, D. Pressure Fluctuations in the S-Shaped Region of a Reversible Pump-Turbine. Energies 2017, 10, 96. [CrossRef]

22. Liu, L.; Zhu, B.; Bai, L.; Liu, X.; Zhao, Y. Parametric Design of an Ultrahigh-Head Pump-Turbine Runner Based on Multiobjective Optimization. Energies 2017, 10, 1169. [CrossRef]

23. Lanahan, M.; Tabares-Velasco, P.C. Seasonal Thermal-Energy Storage: A Critical Review on BTES Systems, Modeling, and System Design for Higher System Efficiency. Energies 2017, 10, 743. [CrossRef]

24. Benato, R.; Bruno, G.; Palone, F.; Polito, R.M.; Rebolini, M. Large-Scale Electrochemical Energy Storage in High Voltage Grids: Overview of the Italian Experience. Energies 2017, 10, 108. [CrossRef] 